\title{
Ireland: Extended Arrangement-Interim Review Under the Emergency Financing Mechanism
}

In the context of the Extended Arrangement with Ireland under the Emergency Financing Mechanism, this staff report on the Extended Arrangement-Interim Review Under the Emergency Financing Mechanism was prepared by a staff team of the International Monetary Fund. It is based on the information available at the time it was completed on February 2, 2011. The views expressed in this document are those of the staff team and do not necessarily reflect the views of the government of Ireland or the Executive Board of the IMF.

The policy of publication of staff reports and other documents by the IMF allows for the deletion of market-sensitive information.

Copies of this report are available to the public from

International Monetary Fund • Publication Services $70019^{\text {th }}$ Street, N.W. • Washington, D.C. 20431

Telephone: (202) 623-7430 • Telefax: (202) 623-7201

E-mail: publications@imf.org Internet: http://www.imf.org

\section{International Monetary Fund Washington, D.C.}




\title{
INTERNATIONAL MONETARY FUND
}

\section{IRELAND \\ Extended Arrangement-Interim Review Under the Emergency Financing Mechanism}

\author{
Prepared by the European Department \\ (In consultation with other departments) \\ Approved by Ajai Chopra and Martin Mühleisen
}

February 2, 2011

Summary. Program implementation has been on target despite the uncertain political environment. Economic indicators suggest that a modest export-led recovery is under way. In the banking sector, progress is being made towards recapitalizing, deleveraging, resolving nonviable banks, and strengthening the bank resolution framework. However, the sector remains under stress and both bank and sovereign spreads have remained elevated and volatile. Fiscal performance has been in line with program targets and the approved Finance Bill will facilitate implementing the fiscal program for 2011. Efforts are under way to address the data gaps and strengthen data quality.

Discussions. The authorities have put in place robust procedures for program implementation and monitoring, but restoring market confidence will depend on determined policy implementation. The start of the process of overhauling the Irish banking system is encouraging, but the outstanding challenges are significant. The simultaneous implementation of the interdependent core elements of the programrecapitalizing, deleveraging and resolving the nonviable parts of the banking system - will be require difficult choices given the inherited stress in the banking system. The fragile political environment could create unwarranted delays.

Staff. The staff team that visited Dublin in January 2011 for the interim review comprised L. Cortavarria-Checkley (head, MCM), J. Mathisen (EUR),

A. Buffa di Perrero (MCM), and B. Kelmanson (SPR); M. Van Wersch and P. Khay (STA) overlapped on a technical assistance mission. Staff teams from the European Commission and the European Central Bank joined the mission for many of the meetings. 


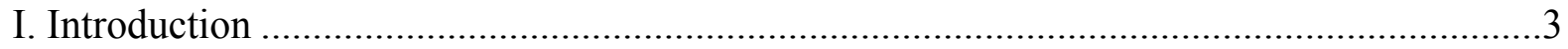

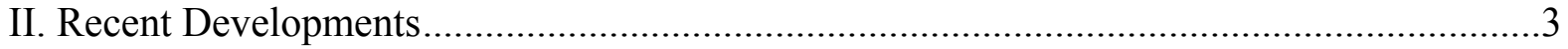

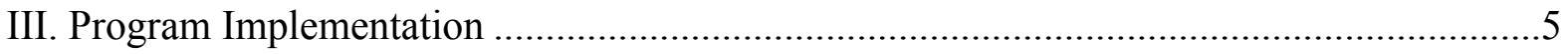

IV. Data Reporting, Program Monitoring, and Safeguards ............................................6

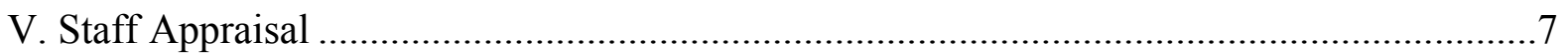

Table

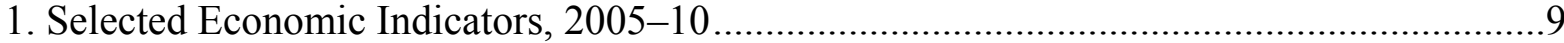




\section{INTRODUCTION}

\section{On December 6, 2010 the Executive Board approved a three-year Extended} Arrangement under the Extended Fund Facility (EFF) for Ireland under the exceptional access policy and Emergency Financing Mechanism (EFM). The arrangement provides access in an amount of SDR 19.5 billion ( $€ 22.5$ billion, US\$30 billion, 2,321.8 percent of Ireland's quota) and is part of an overall financing package of $€ 85$ billion, with $€ 45$ billion from the European Union and bilateral European financing and the rest from self-financing by the Irish. SDR 5 billion became available on approval of the Extended Arrangement, and was purchased by Ireland on January 18, 2011 in parallel with the first EU disbursement. The EFM procedures call for a review of the initial policy response and reaction of markets to the policies within one to two months of the approval of the arrangement. To that end, a mission visited Dublin during January 19-21.

\section{RECENT DEVELOPMENTS}

2. Program implementation is on-track. The two end-December 2010 structural benchmarks - preparation of terms of reference for the diagnostic study and definition of scenarios for the stress tests - have been implemented. The end-December quantitative performance criterion for the exchequer primary balance, the continuous performance criterion on external payment arrears, and the end-December indicative target on central government net debt were met.

3. Political developments have been turbulent. The Prime Minister declared a formal end to his government following the loss of his parliamentary majority. Parliament was dissolved on February 1 and early elections have been set for February 25. The public response to the program has remained favorable, but a lingering domestic perception of inequitable burden sharing persists.

4. The banking sector remains under stress. Bank asset quality as well as real estate prices continue to deteriorate in line with expectations, and the needed provisioning is keeping bank profits in negative territory. Pressure from corporate deposit outflows have moderated, however, and retail deposits continue to be relatively stable. With virtually no access to market funding, reliance on liquidity from the Eurosystem and Emergency Liquidity Assistance (ELA) remains heavy.

ECB's Securities Markets Programme (SMP) and change in Irish spread with German bund (10 day moving avg. in basispoints)

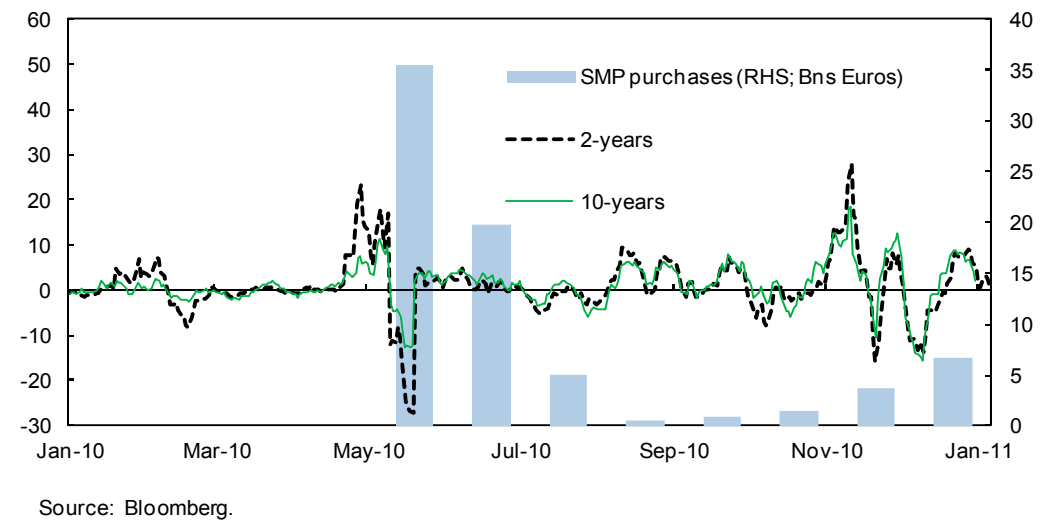




\section{Market reaction to approval of the Extended Arrangement has been mixed.}

Spreads on sovereign bonds have fallen on days when the ECB reportedly bought sovereign paper but have tended to creep back up again and remain elevated and volatile. The volatility at the shortend of the curve has been related to political uncertainty. The downgrade of sovereign ratings by two agencies - Fitch and Moody's - implied that some portion of the collateral posted for ECB liquidity support has become ineligible by ECB criteria and, therefore, was reclassified as ELA provided by the Central Bank of Ireland.
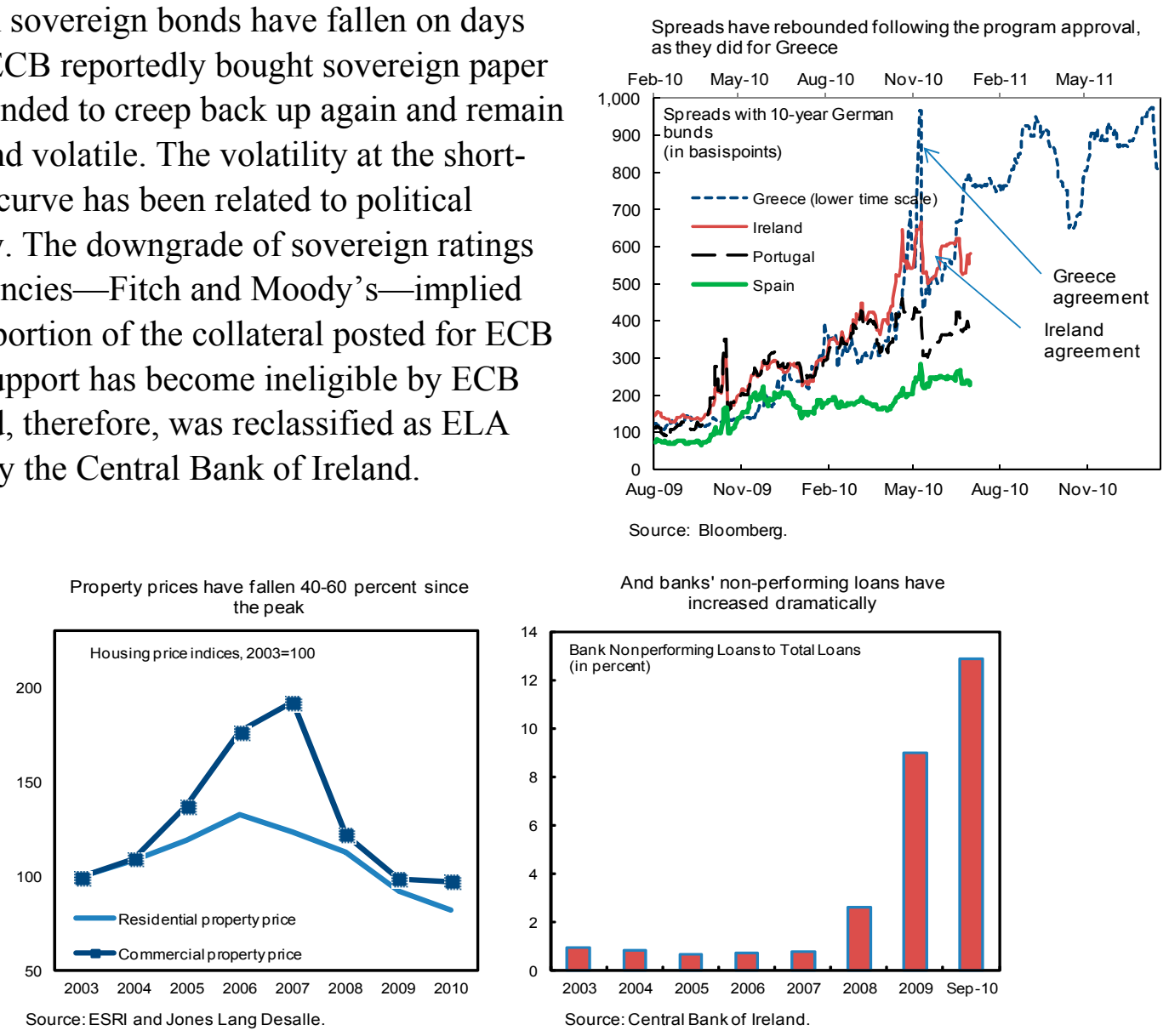

6. There are signs of a modest export-led recovery. Real GDP grew q-o-q by $1 / 2$ percent in 2010:Q3, which was broadly in line with expectations of a $1 / 4$ percent contraction for the full year. The Q3 GDP growth was mainly due to net exports, as domestic demand continued to contract. Revenue in 2010 was higher than anticipated by 0.7 percent of GDP, mainly due to stronger corporation and excise taxes, while the personal income tax

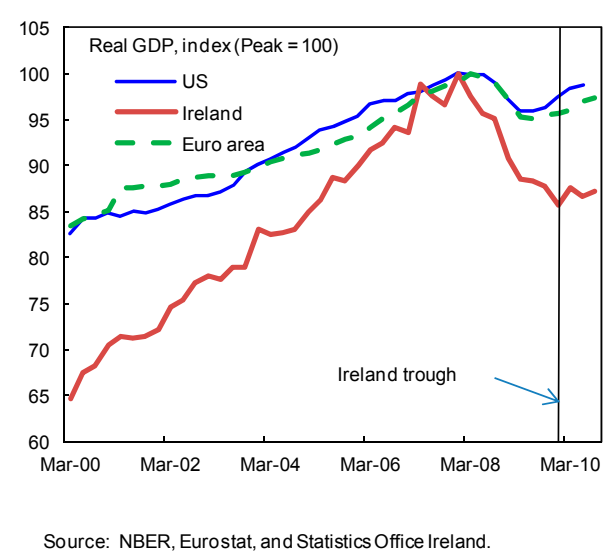

Source. NBER, Eurostat, and Statistics Office Ireland.

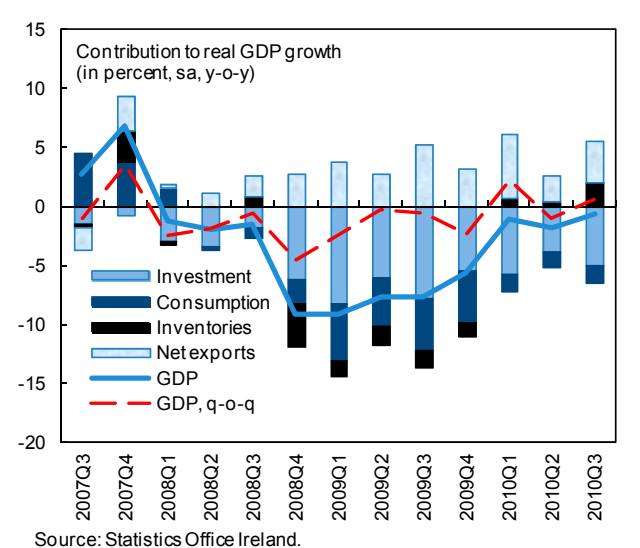

Source: Statistics Office Ireland. 
was weak. Unemployment remains around $13 \frac{1}{2}$ percent, but emigration continues, with Canada, Australia, the U.K., and the U.S. as primary destinations for Irish nationals. This indicates that expectations of a short-term recovery remain soft—migration tends to reverse only when growth is relatively firmly reestablished.

\section{Program Implementation}

\section{The authorities are moving ahead with a comprehensive strategy to restore confidence in the banking sector:}

a. Immediate recapitalization. A process to inject fresh equity into the core banks to achieve a 12 percent of core tier 1 capital ratio has been initiated. This is due to be completed by end-February 2011 (structural benchmark).

b. Steady-state capital ratios. A series of top down stress tests (PCAR 2011), and bottom up diagnostic asset valuations on a bank-by-bank basis will provide a comprehensive picture of banks' asset quality and vulnerabilities (by end-March). The authorities have retained experienced consultants to provide the independent bottom-up diagnostic asset valuation, as well as a thorough validation of bank data and evaluation of bank collateral. This will allow a robust estimate of the additional capital needed to achieve a core tier 1 capital ratio of 10.5 percent on a steady-state basis, as specified in the program. The adverse scenario under the stress tests will require a minimum capital ratio of 6 percent, in line with the pan-European stress tests planned for later in the year under the aegis of the European Banking Authority. The authorities are working closely with their European partners and Fund staff to ensure that bank capital will be sufficient to meet the requirements of both the steadystate and adverse case stress tests simultaneously.

c. Deleveraging. The banks have been required to submit deleveraging plans by endFebruary 2011 and the Irish authorities are working with a well-known investment bank to assist them in assessing the plans against criteria agreed with the IMF, ECB and the EC. The optimal pace of deleveraging must be consistent with achieving the program objectives and safeguarding fiscal sustainability.

d. Strengthening the bank resolution framework. Draft legislation for a special bank resolution regime (end-February structural benchmark) has been developed, covering the agreed provisions for: (i) the appointment of a special manager; (ii) the Central Bank to transfer the troubled institution's assets and liabilities to other institutions; and (iii) the establishment of bridge banks. Fund staff is in the process of providing feedback on the draft. Approval of the finalized legislation by the next government would pave the way for submission to parliament. 
e. Addressing financial weaknesses of credit unions. So far, a thorough financial examination of about half of the 400 credit unions has been completed. The full set of assessments will be the basis for a strategy to enhance the viability of the sector.

8. The program objectives for the financial sector, while simple and straightforward, require complex strategies for implementation. The objectives are to achieve a leaner, more robust banking system with a stable funding base not dependent on government support. In practice, this requires a fundamental restructuring of the banking sector, which had grown disproportionately relative to the size of the Irish economy. The forthcoming deleveraging will therefore involve a careful calibration of tradeoffs, such as balancing objectives for banks' liquidity ratios against the risks of asset fire sales and fuelling a credit crunch. The process will likely result in bank-by-bank deleveraging strategies taking into account potential losses on sales of non-core assets and the resources available after meeting the new regulatory capital requirements.

9. Fiscal performance is in line with program targets. The performance criterion on the exchequer primary balance at end-December 2010 was met with a margin of $3 / 4$ percent of GDP. On the revenue side, collections in November and December (representing about $1 / 4$ of annual receipts) were higher than expected by 0.4 percent of GDP. On the expenditure side, staff had expected a higher take-up rate for the exit package for health sector employees, and somewhat higher social protection and capital spending than was observed. In line with program definitions, the performance criterion was adjusted for bank support, reflecting the $€ 525$ million (0.3 percent of GDP) injection into EBS on December 14. The (adjusted) indicative target on central government net debt for end-2010 was also met.

10. The Finance Bill, a key step in implementing the fiscal program, was approved by Parliament on January 29. The Finance Bill gives effect to the taxation measures announced in the 2011 budget with some minor modifications. The abolition of the propertyrelated tax expenditure will now likely take effect in 2012, following the preparation and publication of an economic impact assessment. The universal social charge, which replaces the health and income levies, will be reduced from 7 percent announced in the budget to 4 percent for medical card holders, to be offset by increasing the rate paid by self-employed taxpayers from 7 to 10 percent on incomes above $€ 100,000$. However, the overall budget targets and the objectives of the National Recovery Plan, and thus the IMF program targets, are respected.

\section{Data Reporting, Program Monitoring, And Safeguards}

\section{Efforts are underway to address data gaps and further strengthen data quality.}

A technical assistance mission from STA overlapped with the interim review mission in January 2011. Staff worked closely with central bank and central statistical office staff to develop methods for reporting on debt service payments (interest and amortization) broken down by sector and instrument. In addition, a work program was agreed to enable a 
distinction to be made between assets and liabilities of the domestic Irish banking sector, and those of the International Financial Center located in Dublin. This will help analysis of the Irish banking system by disentangling it from international institutions operating in Ireland.

12. Robust procedures for program monitoring have been established. The authorities have established a centralized unit to coordinate and assist in program implementation and monitoring. The unit, based in the Department of Finance, will coordinate with representatives from the central bank, NTMA, and other government agencies. The unit has established procedures for reporting and assessing program performance. The authorities emphasized the need to ensure that the monitoring mechanisms be as streamlined as possible, including with the European institutions.

13. A safeguards assessment of the Central Bank of Ireland is in progress and will be completed by the time of the first review under the Extended Arrangement. A mission visited Dublin during January 10-17, 2011 and found that the CBI had a generally sound framework.

\section{Staff Appraisal}

14. Turning market sentiment to a more positive tone will require sustained implementation and reduced political uncertainty. Concerns regarding the ability to maintain policy momentum during the political transition are contributing to market uncertainty. A lasting reduction in spreads will likely require a sustained period of strong policy implementation and improved economic outcomes. Especially important will be decisive action to restore the health of the banking sector to support the real economy and create jobs.

\section{Mechanisms for effective program implementation and monitoring have been} put in place. The authorities have established a central unit in the Department of Finance to coordinate program implementation across government bodies. The unit is also responsible for reporting on progress under the program. This bodes well for the implementation of the program supported by the Extended Arrangement.

\section{While the good start of the process to overhaul the Irish banking system is} encouraging, the outstanding challenges are significant. Simultaneously recapitalizing, deleveraging and resolving the nonviable parts of the banking system - in a transparent and competitive manner-would be difficult even in the best of circumstances. Moreover, given that the various elements are interdependent, the inherited stress in the banking system makes implementing a comprehensive and coherent strategy a major operational challenge. For example, the deleveraging process hinges on the accuracy of the asset valuation, the difficulty of which is exacerbated due to market uncertainty.

17. Flexibility in program design will be important to address the challenges ahead. This will require defining structural benchmarks related to the implementation process 
underlying the emerging banking sector strategy (e.g., on how to deleverage various types of assets), complemented by indicative quantitative goals. Doing so will ensure that the restructuring process will deliver the established goal of a leaner, more robust banking system with a stable funding base.

18. Due to the imminent elections, the first and second review of the program will be combined and conducted only when the government is in place. In the meantime, technical discussion will continue to assess progress and discuss operational aspects of policy implementation to achieve the objectives under the program. 
Table 1. Ireland: Selected Economic Indicators, 2005-10

(Annual change unless otherwise stated)

\begin{tabular}{|c|c|c|c|c|c|c|}
\hline & & & & & & Prel. \\
\hline & 2005 & 2006 & 2007 & 2008 & 2009 & 2010 \\
\hline \multicolumn{7}{|l|}{ National accounts (constant prices) } \\
\hline GNP & 6.0 & 6.5 & 4.5 & -3.5 & -10.7 & -2.4 \\
\hline GDP & 6.0 & 5.3 & 5.6 & -3.5 & -7.6 & -0.2 \\
\hline Domestic demand & 8.8 & 6.4 & 5.4 & -5.1 & -13.9 & -4.4 \\
\hline Private consumption & 6.9 & 6.7 & 6.4 & -1.5 & -7.0 & -1.3 \\
\hline Public consumption & 3.9 & 5.1 & 6.9 & 2.2 & -4.4 & -3.7 \\
\hline Gross fixed investment & 14.9 & 4.6 & 2.8 & -14.3 & -31.0 & -20.6 \\
\hline Net exports $1 /$ & -2.0 & -0.8 & 0.8 & 1.5 & 3.8 & 3.6 \\
\hline Exports of goods and services & 4.8 & 4.8 & 8.2 & -0.8 & -4.1 & 8.8 \\
\hline Imports of goods and services & 8.3 & 6.4 & 7.8 & -2.9 & -9.7 & 5.5 \\
\hline Gross national saving (in percent of GDP) & 23.6 & 24.8 & 21.7 & 16.4 & 11.5 & 10.4 \\
\hline Private & 18.8 & 18.4 & 18.7 & 20.6 & 25.2 & 24.5 \\
\hline Public & 4.8 & 5.9 & 3.0 & -4.2 & -13.8 & -14.1 \\
\hline Gross investment (in percent of GDP) & 27.2 & 28.0 & 27.3 & 22.3 & 14.1 & 11.8 \\
\hline Private & 23.7 & 24.2 & 22.5 & 16.8 & 9.4 & 7.4 \\
\hline Public & 3.5 & 3.8 & 4.8 & 5.5 & 4.7 & 4.4 \\
\hline \multicolumn{7}{|l|}{ Prices, wages and employment } \\
\hline Harmonized Index of Consumer Prices (annual average) & 2.2 & 2.7 & 2.9 & 3.1 & -1.7 & -1.6 \\
\hline Average wages, all economy & 5.1 & 5.5 & 5.2 & 3.5 & -1.0 & -1.7 \\
\hline Output, manufacturing & 4.1 & 3.1 & 5.3 & -2.1 & -7.2 & -0.2 \\
\hline GNP/employment & 1.0 & 2.1 & 0.8 & -2.4 & -2.7 & 1.9 \\
\hline Employment & 4.9 & 4.4 & 3.6 & -1.1 & -8.1 & -4.3 \\
\hline Unemployment rate (in percent) & 4.4 & 4.4 & 4.6 & 6.3 & 11.8 & 13.3 \\
\hline \multicolumn{7}{|l|}{ Money and credit (end-period) } \\
\hline Irish contribution to euro area money supply: M3 & 22.1 & 28.5 & 9.6 & -1.9 & -1.5 & $\ldots$ \\
\hline Irish resident private sector credit $2 /$ & 28.8 & 25.9 & 17.0 & 7.3 & -7.6 & $\ldots$ \\
\hline \multicolumn{7}{|l|}{ Financial and asset markets (end-period) } \\
\hline Three-month interbank rate & 2.5 & 3.7 & 4.6 & 3.0 & 0.6 & 0.9 \\
\hline 10-year government bond & 3.3 & 4.0 & 4.5 & 4.4 & 4.9 & 9.2 \\
\hline ISEQ index & 16.8 & 27.8 & -26.3 & -66.2 & 27.0 & -3.0 \\
\hline House prices (permanent tsb index/ESRI) & 9.4 & 11.8 & -6.9 & -8.8 & -18.5 & -10.8 \\
\hline \multicolumn{7}{|l|}{ Public finance (in percent of GDP) } \\
\hline General government balance & 1.6 & 2.9 & 0.1 & -7.3 & -14.4 & -31.7 \\
\hline Primary balance & 2.7 & 3.8 & 0.9 & -6.3 & -12.3 & -28.6 \\
\hline General government debt & 27.2 & 24.8 & 25.0 & 44.4 & 65.6 & 94.5 \\
\hline \multicolumn{7}{|l|}{ External trade and balance of payments } \\
\hline Balance of goods and services (percent of GDP) & 11.7 & 10.3 & 9.9 & 9.0 & 15.0 & 19.0 \\
\hline Current account (percent of GDP) & -3.5 & -3.6 & -5.3 & -5.6 & -3.0 & -1.9 \\
\hline \multicolumn{7}{|l|}{ Effective exchange rates (1999:Q1=100, annual average) } \\
\hline Nominal & 104.1 & 104.4 & 107.4 & 113.0 & 112.5 & $\ldots$ \\
\hline Real (CPI based) & 115.4 & 116.0 & 120.1 & 125.6 & 121.9 & ... \\
\hline \multicolumn{7}{|l|}{ Memorandum items: } \\
\hline Population (in millions) & 4.1 & 4.2 & 4.3 & 4.4 & 4.5 & 4.5 \\
\hline GDP per capita (in euros) & 39,265 & 41,828 & 43,645 & 40,702 & 35,801 & 35,065 \\
\hline
\end{tabular}

Sources: Department of Finance; Central Bank of Ireland; IFS; Bloomberg; and Fund staff calculations.

1/ Contribution to growth. However, the data for exports and imports of goods and services are annual growth rates. 2/ Adjusted change, which includes the effects of transactions between credit institutions and non-bank international financial companies and valuation effects arising from exchange rate movements. 